Announcement

\title{
The \\ Journal of Policy History
}

announces a

\section{Policy History Conference}

commemorating the completion of its tenth year of publication.

The conference will be held May 27 through 30, 1999 in St. Louis, Missouri.

For more information contact:

Policy Conference Journal of Policy History Saint Louis University 3800 Lindell Blvd. St. Louis, MO 63156 


\section{Forthcoming Articles}

Suzanne Mettler (Syracuse University), "The Stratification of Social Citizenship: Gender and Federalism in the Formation of Old Age Insurance and Aid to Dependent Children"

Joel H. Silbey (Cornell University), "The State and Practice of American Political History at the Millennium: The Nineteenth Century as a Test Case"

John Gerring (Boston University), "Does Party Ideology Matter? A Rolecall Analysis of Key Congressional Votes, 1833-1992"

Gail Radford (State University of New York, Buffalo), "William Gibbs McAdoo, the Emergency Fleet Corporation, and the Origins of the PublicAuthority Model of Government Action"

Ann-Marie Szymanski, (University of Oklahoma), "Dry Compulsions: Prohibition and the Creation of State-Level Enforcement Agencies"

\section{Special Issues}

Otis Graham (University of North Carolina, Wilmington), "Environmental Politics and Policy, 1960s-1990s" (Winter, 2000)

Hugh Heclo (George Mason University) "Religion, Politics, and Policy" (Winter, 2001) 


\section{Building the Invisible Orphanage}

\section{A Prehistory of the American Welfare System}

\section{MATTHEW A. CRENSON}

This book examines the connection between the decline of the orphanage and the rise of welfare in America. Matthew Crenson argues that the prehistory of the welfare system was played out not on the stage of national politics or class conflict but in the micropolitics of institutional management. New arrangements for child welfare policy emerged gradually as superintendents, visiting agents, and charity officials responded to the difficulties that they encountered in running orphanages or creating systems that served as alternatives to institutional care. Crenson also follows the decades-long debate about the relative merits of family care or institutional care for dependent children.

$\$ 45.00$ cloth

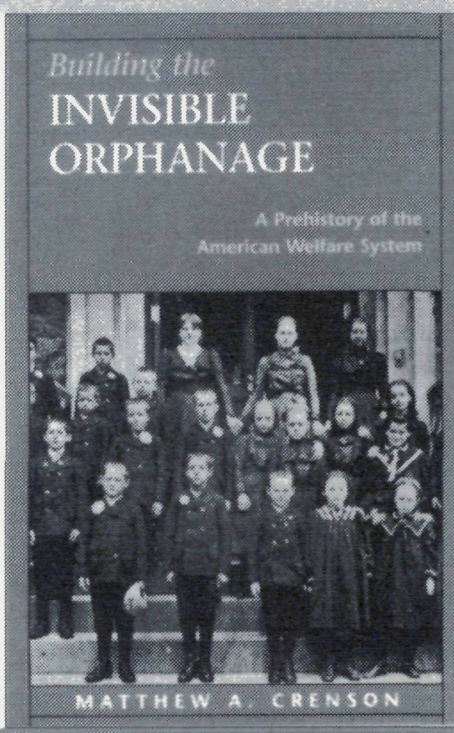

phone: 800.448.2242 • HARVARD UNIVERSITY PRESS • www.hup.harvard.edu 